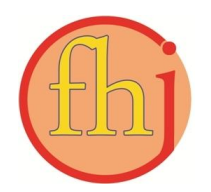

Faletehan Health Journal, 6 (2) (2019) 51-55

www.journal.Ippm-stikesfa.ac.id/ojs/index.php/FHJ

ISSN 2088-673X | e-ISSN 2597-8667

\title{
Analisis Penggunaan Gadget Terhadap Pola Komunikasi Keluarga
}

\author{
Herna Alifiani ${ }^{1 *}$, Nurhayati $^{1}$, Yulia Ningsih ${ }^{1}$ \\ 1Program Studi IImu Keperawatan STIKes Faletehan Serang Banten, Indonesia \\ *Corresponding Author: hernaalifiani01@yahoo.com
}

\begin{abstract}
Abstrak
Saat ini gadget sudah menjadi kebutuhan penting bagi manusia. Perkembangan teknologi yang semakin bertambah maju, berpengaruh langsung pada bidang komunikasi, informasi dan hiburan. Meningkatnya jumlah pengguna gadget memiliki dampak negatif bagi manusia salah satunya adalah menurunnya pola komunikasi efektif antara remaja dengan orang tua. Tujuan penelitian ini untuk mengetahui hubungan penggunaan gadget terhadap pola komunikasi keluarga pada siswa-siswi kelas X di SM K Yabhinka Kota Cilegon tahun 2018. Penelitian ini merupakan penelitian deskriptif korelasi dengan metode cross sectional. Jumlah sampel 76 siswa. Peneliti menggunakan instrumen berupa kuesioner. Hasil penelitian menunjukan dari 45 responden dengan penggunaan gadget sering terdapat 44 orang $(97,8 \%)$ yang pola komunikasi dengan keluarganya kurang baik dan $1(2,2 \%)$ yang pola komunikasi dengan keluarganya baik. Dari 32 responden dengan penggunaan gadget kadang-kadang terdapat 5 orang $(15,6 \%)$ yang pola komunikasi dengan keluarganya kurang baik dan 27 orang $(84,4 \%)$ yang pola komunikasi dengan keluarganya baik. Hasil uji chi square menunjukan nilai $p=0,000(<0,05)$ dan nilai OR (Odss Ratio) 237. Disimpulkan ada hubungan antara penggunaan gadget terhadap pola komunikasi dengan keluarga.
\end{abstract}

Kata Kunci: Gadget, Keluarga, Pola Komunikasi

\begin{abstract}
Nowadays gadgets have become an important requirement for humans. Increasingly advanced technological developments have a direct influence on the fields of communication, information and entertainment. The increasing number of gadget users has a negative impact, where one of them decreases the effective communication pattern between adolescents and parents. The purpose of this study was to determine the relationship of the Use of Gadgets to Family Communication Patterns in Class X Students at SMK Yabhinka Cilegon in 2018. This study used a descriptive correlation study with a cross sectional. total samples 76 students. The researcher used the instrument gadget usage questionnaire and a pattern of communication with the family questionnaire. The results showed that of the 45 respondents with the use of gadgets there were often 44 people (97.8\%) whose communication patterns with their families were not good and $1(2.2 \%)$ whose pattern of communication with their families was good. 32 respondents with the use of gadgets sometimes have 5 people (15.6\%) whose communication patterns with their families are not good and 27 people (84.4\%) have good communication patterns with their families. The results of the chi square test show the value of $p=0,000(\varangle 0.05)$ and the value of OR (Odss Ratio) 237. Conclude there is a relationship between the use of gadgets to patterns of communication with families.

Keywords: Gadgets, Communication Style, Familly
\end{abstract}


Faletehan Health Journal, 6 (2) (2019) 50-55

www. journal.Ippm-stikesfa.ac.id/ojs/index.php/FHJ

ISSN 2088-673X | 2597-8667

\section{Pendahuluan}

Perubahan sosial dan longgarnya nilai-nilai keluarga perlahan-lahan telah merenggangkan kedekatan dan mengurangi intensitas komunikasi remaja dengan keluarga (Pramono, 2017). Penelitian mengungkapkan perubahan pola komunikasi pada remaja banyak di pengaruhi karena penggunan gadget, dimana pengguna gadget cenderung mengabaikan keberadaan orang di sekitar mereka ketika sedang asyik mengoperasikan perangkat elektronik tersebut (Anita, 2010).

Violence \& Gore (dalam Mubarok, 2013) yang menyatakan bahwa Antisosial Behaviour merupakan dampak negative gadget yang disebabkan karena penyalahgunaan gadget itu sendiri. Hal ini terjadi dimana ketika seseorang merasa gadget merupakan satu-satunya hal yang paling penting dalam hidupnya, sehingga melupakan keadaan disekitarnya. Munculnya ketidakpedulian dalam diri seseorang terhadap lingkungannya. Satu-satunya hal yang dapat menarik perhatiannya hanyalah gadget yang gunakannya. Akibat yang timbul ialah dia menjadi jarang berinteraksi dengan orang - orang yang berada di lingkungan sekitarnya, sehingga dia akan kesulitan untuk bersosialisasi dan menjalin relasi dengan orang-orang di sekitarnya.

Perkembangan teknologi saat ini semakin hari kian bertambah maju, hal ini berpengaruh pada bidang komunikasi, informasi dan hiburan sehingga terjadi peningkatan angka penggunaan gadget. Saat ini gadget menjadi sebagai salah satu kebutuhan penting bagi masyarakat, dimana pengguna gadget bukan hanya dari kalangan orang dewasa, remaja dan anak-anak pun sudah menjadi pengguna gadget. Gadget menyajikan berbagai media yang menarik mulai dari berita, jejaring sosial, informasi gaya hidup, hingga berbagai hiburan seperti game yang disajikan secara online maupun offline membuat gadget semakin menarik banyak perhatian masyarakat luas. Tetapi dari banyaknya kelebihan yang telah ditawarkan dari suatu gadget, juga terdapat banyak dampak negatif bermunculan. Bentuk pendekatan komunikasi yang paling ideal adalah yang bersifat transaksional, dimana proses komunikasi dilihat sebagai suatu proses yang sangat dinamis dan timbal balik.

Kebutuhan akan gadget di era digital ini sudah seperti kebutuhan primer, dimana semua kalangan baik itu anak-anak, remaja, dewasa hingga orang tua sudah memiliki gadget di genggamannya dengan bentuk dan kebutuhan yang beragam. Kemajuan teknologi yang semakin hari semakin canggih, ditambah dengan sajian aplikasi menarik membuat pengguna gadget tidak bisa lepas untuk menggunakannya. Aplikasi atau fitur dari gadget yang dikemas sangat menarik membuat anak betah berlama-lama bermain gadget, sehingga efek yang ditimbulkan menyebabkan anak menjadi malas bergerak, beraktivitas dan berinteraksi sosial dengan lingkungan sekitar karena komunikasi sudah biasa terwakili dalam dunia digital (Yusuf, 2015).

Peningkatan jumlah penggunaan gadget di era modern ini selain karena fitur atau sajian aplikasi yang menarik, gadget juga semakin mudah di dapat serta terjangkaunya harga dari ponsel cerdas atau dikenal dengan istilah gadget tersebut (Sanjaya \& Wibhowo, 2011). Saat ini pengguna smartphone di Indonesia terus meningkat. Sebuah lembaga riset menyebutkan bahwa Indonesia berada di peringkat kelima daftar pengguna smart-phone terbesar di dunia. Data tersebut dilansir oleh Horace H. Dediu melalui blognya, asymco.com. Pada laman detik.com tertulis jika populasi Android telah mrncapai lebih dari 1 miliar, sedangkan iOS mencapai 700 juta.

Menurut Iskandar (2014) Indonesia masuk dalam daftar 10 negara dengan penjualan smartphone terbanyak di dunia antara lain diperingkat pertama adalah Brasil dengan 47 juta penjualan dan 38,2 juta pengguna baru, Indonesia dengan 46 juta penjualan dan 39,8 juta pengguna baru, Rusia dengan 31 juta penjualan dan 21,4 juta pengguna baru, Jepang dengan 30 juta penjualan dan 22,9 juta pengguna baru, Meksiko dengan 23 juta penjualan dan 16,3 juta pengguna baru, Jerman dengan 22 juta penjualan dan 12,2 juta pengguna baru, Prancis dengan 18,7 juta penjualan dan 11,21 juta pengguna baru, dan terakhir adalah Inggris dengan 17,7 juta penjualan dan 8,24 juta pengguna baru.

Menurut lembaga riset pasar e-Marketer pengguna aktif gadget khususnya penggunaan smartphone di Indonesia akan tumbuh dari 55 juta orang pada tahun 2015 menjadi 100 juta orang tahun 2018. Dengan jumlah tersebut, Indonesia akan menjadi negara dengan pengguna aktif smartphone terbesar keempat di dunia setelah China, India, dan Amerika (kominfo, 2017). 
Perkembangan teknologi saat ini bagaikan dua mata pisau yang perlu mendapatkan perhatian khusus dari semua elemen, tidak bisa dipungkiri bahwa di balik manfaat penggunaan gadget, juga menimbulkan dampak yang mengkhawatirkan, mulai dari pornografi, penurunan kualitas belajar pada siswa, kekerasan, dan banyak lagi yang semua bermula dari penggunaan gadget (kominfo, 2014).

Remaja merupakan individu harapan bangsa, kehidupan keluarga, bangsa dan Negara kelak dimasa depan ditentukan oleh kualitas remaja saat ini. Remaja sebagai generasi harapan bangsa, harus memiliki potensi dan kemampuan dalam membangun kehidupan, remaja juga perlu memiliki konsep diri yang positif untuk memahami dan mengenal dirinya, karena remaja merupakan perhatian khusus bagi masyarakat dan pemerintah (Kemenkes, 2012). Bila dilihat dari komposisi usia, persentase pengguna gadget yang termasuk kategori usia anak-anak dan remaja di Indonesia cukup tinggi, yaitu 79,5 persen. Survei yang dilakukan oleh Kementerian Informasi dan Unicef tahun 2014 itu menggambarkan pula bahwa anak dan remaja menggunakan gadget sebagian besar untuk mencari informasi, hiburan, serta menjalin relasi sosial (Liputan6, 2016).

Masa remaja merupakan periode transisi yang ditandai dengan perubahan individu dalam segala aspek baik fisik, sosial, psikologi, dan mental (Djamarah dan Bahri, 2004). Selama periode ini, kebutuhan remaja untuk mengekspresikan diri dan bersosialisasi dengan teman sebayanya berkembang pesat. Saat masa remaja ini, komunikasi khususnya komunikasi pada keluarga berperan penting dalam proses perkembangan intelektual dan emosional remaja. Komunikasi keluarga yang efektif dapat membangun hubungan yang positif antar anggota keluarga, menyampaikan pengetahuan, mengubah perilaku, dan memecahkan masalah. Keluarga diharapkan dapat memberikan suasana yang kondusif bagi perkembangan intelektual dan emosional remaja (Djamarah dan Bahri, 2004).

\section{Metode Penelitian}

Penelitian ini menggunakan penelitian deskriptif korelasi dengan metode pendekatan cross sectional. Penelitian dilakukan di SMK Yabhinka Kota Cilegon pada bulan Juni 2018. Populasi dalam penelitian ini adalah seluruh siswasiswi kelas X di SMK Yabhinka Kota Cilegon yang berjumlah 357 siswa. Pengambilan sampel digunakan melalui rumus sampling Nursalam (2009):

$$
n=\frac{Z^{2} 1-\alpha /^{2} \cdot P(1-P) \cdot N}{d^{2}(N-1)+Z^{2} 1-\alpha /{ }_{2} P(1-P)}
$$

Berdasarkan rumus diatas, maka jumlah sampel minimal yang harus diambil dalam penelitian adalah 76,82 siswa dibulatkan menjadi 77 siswa. Penentuan sampel menggunakan simple random sampling.

Penelitian ini menggunakan instrumen berupa kuesioner yang disusun oleh peneliti dimana isinya disesuaikan dengan tinjauan teori. Penelitian ini menggunakan instrumen yang berupa kuesioner, yaitu kuesioner penggunaan gadget dan kuesioner pola komunikasi. Kuesioner penggunaan gadget berisi 17 pernyataan menggunakan skala likert yang dikategorikan sering apabila mendapatkan jumlah nilai < 46,66 (mean), dikategorikan kadang-kadang apabila mendapatkan nilai $\geq 46,66$ (mean). Kuesioner pola komunikasi dengan keluarga berisi 18 pernyataan dengan skala likert, pola komunikasi dengan keluarga dikategorikan kurang baik apabila mendapatkan jumlah nilai < 49,65 (mean) dan dikategorikan baik apabila mendapatkan nilai $\geq 49,65$ (mean).

\section{Hasil dan Pembahasan}

Berdasarkan tabel 1 diperoleh hasil penggunaan gadget pada siswa-siswi kelas $\mathrm{x}$ di SMK Yabhinka Kota Cilegon tahun 2018, dari 77 responden terdapat 45 orang $(58,4 \%)$ yang sering menggunakan gadget. Melihat hasil penelitian tersebut dapat disimpulkan bahwa siswa sebagai pengguna gadget aktif. Hal ini dapat dilihat bahwa penggunaan gadget merupakan hal biasa yang dapat dilakukan siswa di sekolah ataupun di rumah.

Tabel 1. Distribusi Penggunaan Gadget Pada Siswa-Siswi

\begin{tabular}{ccc}
\hline Variabel & F & \% \\
\hline Sering & 45 & 58,4 \\
Kadang-kadang & 32 & 41,6 \\
\hline Total & $\mathbf{7 7}$ & $\mathbf{1 0 0}$ \\
\hline
\end{tabular}

Pihak sekolah memperbolehkan siswa untuk membawa gadget ke sekolah karena hal ini juga dipandang baik oleh pihak sekolah untuk menunjang aktifitas kegiatan belajar mengajar (KBM) dan mengajarkan siswa untuk tidak gaptek (gagap teknologi) sehingga siswa dapat mengikuti perkembangan jaman di era modern ini. Kebijakan 
Faletehan Health Journal, 6 (2) (2019) 50-55 www. journal.Ippm-stikesfa.ac.id/ojs/index.php/FHJ ISSN 2088-673X | 2597-8667

sekolah yang memperbolehkan siswa membawa gadget ini ternyata disalahgunakan oleh para siswa, faktanya siswa yang diperbolehkan mengaktifkan gadgetnya pada saat jam pelajaran berlangsung, sering kali tertangkap tangan sedang bermain game online dan mengakses media sosial (facebook, twitter, instagram, pad, whatsapp, BBM) yang dimiliki. Kurangnya kesadaran siswa untuk mematuhi aturan yang ada disekolah dan faktor kecanduan gadget mulai dari bermain game online sampai turut aktif pada sederet akun jejaring sosial media, membuat siswa sulit untuk meninggalkan gadget hingga penggunaan gadget sudah menjadi hal biasa bagi siswa.

Penelitian ini sejalan dengan Karpinski (2009) yang juga memandang penggunaan gadget berlebihan akan berdampak negatif kepada perilaku remaja. Hasil penelitian Karpinski (2009) membuktikan bahwa pemakaian gadget untuk media sosial yang berlebihan dapat mengakibatkan menurunnya prestasi belajar siswa. Temuan Karpinski (2009) menunjukkan bahwa pengguna media sosial yang berlebih memiliki Indeks Prestasi Kumulatif (IPK) yang lebih rendah dari pada siswa yang bukan pengguna situs ini. Menurut Karpinski, hal itu karena penggunaan media sosial menghabiskan waktu untuk online terlalu banyak sehingga kekurangan waktu untuk belajar.

Berdasarkan tabel 2 diperoleh hasil pola komunikasi dengan keluarga pada siswa-siswi kelas $\mathrm{x}$ di SMK Yabhinka Kota Cilegon tahun 2018 , dari 77 responden terdapat 49 orang $(63,6 \%)$ yang pola komunikasi dengan keluarganya kurang baik. Berdasarkan penelitian yang telah dilakukan dapat disimpulkan bahwa pola komunikasi siswa dengan keluarga tidak efektif. Faktor dominannya ialah penyalahgunaan gadget sehingga siswa menjadi pecandu gadget. Penggunaan gadget pada siswa menjadikan waktu dengan orang tua juga berkurang, siswa lebih banyak menghabiskan waktu luangnya dengan bermain gadget yang siswa miliki. Kebiasaan-kebiasaan ketergantungan terhadap media komunikasi gadget ini, menjadikan siswa terus berpikir untuk selalu ingin dan ingin menggunakannya. Gadget yang seharusnya digunakan sebagai media komunikasi jarak jauh dan membantu pengerjaan tugas sekolah justru beralih fungsi menjadi kebutuhan pokok yang menyertai siswa disetiap aktifitas.

Penelitian ini sejalan dengan penelitian Pramono, Lubis, Puspitawati dan Susanto (2017) tentang komunikasi remaja dengan keluarga diera digital, 372 responden berusia 15-18 tahun, media sosial menduduki peringkat kedua setelah sekolah (komunikasi antar teman sebaya) yang dipilih remaja sebagai tempat ternyaman untuk berkomunikasi, sedangkan komunikasi dengan keluarga dirumah menjadi urutan akhir atau urutan ke empat dari kategori nyaman.

Penelitian di AS juga menunjukkan gambaran yang suram mengenai diskoneksi di dalam keluarga. Jumlah keluarga yang mengaku quality time anaknya untuk keluarga kian berkurang oleh karena kesibukan anak mengakses internet naik hampir tiga kali lipat dari $11 \%$ pada 2006 menjadi $28 \%$ pada 2011 (Steiner, Adair and Barker, 2013).

Tabel 2. Distribusi Pola Komunikasi Dengan Keluarga

\begin{tabular}{ccc}
\hline Variabel & F & \% \\
\hline Kurang Baik & 49 & 63,6 \\
Baik & 28 & 36,4 \\
\hline Total & $\mathbf{7 7}$ & $\mathbf{1 0 0}$ \\
\hline
\end{tabular}

Tabel 3. Hubungan Antara Penggunaan Gadget Terhadap Pola Komunikasi Keluarga

\begin{tabular}{|c|c|c|c|c|c|c|c|c|}
\hline \multirow{3}{*}{ Penggunaan Gadget } & \multicolumn{4}{|c|}{ Pola komunikasi dengan keluarga } & \multirow{2}{*}{\multicolumn{2}{|c|}{ Total }} & \multirow{3}{*}{ P. Value } & \multirow{3}{*}{$\mathbf{O R}$} \\
\hline & \multicolumn{2}{|c|}{ Kurang Baik } & \multicolumn{2}{|c|}{ Baik } & & & & \\
\hline & $\mathbf{n}$ & $\%$ & $\mathbf{n}$ & $\%$ & $\mathbf{n}$ & $\%$ & & \\
\hline Sering & 44 & 97,8 & 1 & 2,2 & 45 & 100 & \multirow{3}{*}{0,000} & \multirow{3}{*}{237} \\
\hline Kadang-kadang & 5 & 15,6 & 27 & 84,4 & 32 & 100 & & \\
\hline Total & 49 & 63,6 & 28 & $\mathbf{3 6 , 4}$ & 77 & 100 & & \\
\hline
\end{tabular}

Berdasarkan tabel 3 diperoleh hasil dari 45 responden dengan penggunaan gadget sering terdapat 44 orang $(97,8 \%)$ yang pola komunikasi dengan keluarganya kurang baik dan 1 orang
$(2,2 \%)$ yang pola komunikasi dengan keluarganya baik. Dari 32 responden dengan penggunaan gadget kadang-kadang terdapat 5 orang $(15,6 \%)$ yang pola komunikasi dengan keluarganya kurang 
baik dan 27 orang $(84,4 \%)$ yang pola komunikasi dengan keluarganya baik.

Berdasarkan hasil uji chi square menunjukan bahwa nilai $\mathrm{p}=0,000(<0,05)$ dan nilai OR $($ Ods Ratio) 237, maka dapat disimpulkan bahwa secara statistik terdapat hubungan yang bermakna antara penggunaan gadget terhadap pola komunikasi dengan keluarga pada siswa-siswi kelas X di SMK Yabhinka Kota Cilegon tahun 2018, artinya semakin sering siswa menggunakan gadget maka pola komunikasi dengan keluarga kurang baik.

Siswa yang dapat mengatur waktu penggunaan gadget akan memiliki pola komunikasi yang baik dengan keluarga sehingga terhindar dari dampak buruk yang ditimbulkan dari penggunaan gadget tersebut. Pola komunikasi dengan keluarga merupakan faktor yang sangat penting untuk terbentuknya perilaku atau karakter seseorang, bila siswa mempunyai pola komunikasi dengan keluarga yang kurang baik maka individu tersebut akan cenderung memiliki kepribadian yang buruk pula.

Penelitian ini sejalan dengan penelitian yang dilakukan oleh Pertiwi (2016) mengenai hubungan antara penggunaan gadget dengan pola komunikasi antar pribadi dalam keluarga, hasilnya adalah adanya hubungan antara penggunaan gadget terhadap pola komunikasi anak. Penelitian Manumpil, Ismanto dan Unibala (2015) gadget juga digunakan siswa untuk browsing bahkan paling banyak digunakan untuk bermain game online serta untuk mengakses berbagai media sosial yang ada (Instagram, Path,Facebook, Twitter), mereka cenderung memiliki gadget untuk mengikuti trend yang ada saat ini. Didukung juga oleh penelitian yang dilakukan oleh Nurchayati (2016) mengenai dampak penggunaan gadget terhadap komunikasi keluarga dalam pembentukan karakter, hasilnya adalah sebanyak $78 \%$ dapat menyebabkan kurang komunikatifnya hubungan anak dengan keluarga atau orang tua sedangkan sisanya yang $22 \%$ siswa dapat memanfaatkan gadget sesuai dengan kebutuhan.

Orang tua sebaiknya dituntut untuk tidak gaptek (gagap teknologi) dalam mengontrol dan mendidik anak di era digital. Berdasarkan riset didapatkan sebanyak 96 remaja di dunia menggunakan media sosial dalam kesehariannya dan hanya $15 \%$ orang tua yang mengaku mengetahui media sosial anak-anak mereka. Dapat dikatakan orang tua telah membiarkan anaknya mengeksplorasi dirinya sendiri dengan bebas di dunia maya tanpa pernah bisa memahami dampak yang bisa ditimbulkannya di kemudian hari (Septiyani dan Intan, 2016).

Komunikasi akan dikatakan sukses jika menghasilkan sesuatu yang diharapkan yakni kesamaan pemahaman. Perselisihan dan perbedaan paham akan menjadi sumber persoalan bila tidak ditangani dengan bijaksana, sehingga memerlukan usaha-usaha komunikatif antara anggota keluarga, dalam usaha untuk menyelesaikan persoalan maka pemikiran harus dipusatkan dan ditujukan ke arah pemecahan persoalan, supaya tidak menyimpang dan mencari kekurangan serta kesalahan masingmasing (Nurchayati, 2016).

Komunikasi yang baik antara anak dengan orang tua didasari oleh prinsip keterbukaan. Yaitu bersikap terbuka dan jujur mengenai perasaan/pemikiran masing-masing, tanpa adanya rasa takut dan khawatir untuk mengungkapkannya, kemudian budaya mendengar dan memberi kesempatan, maksudnya adalah kita harus mendengarkan argumen, menerima diri dan menerima orang lain.

Semakin besar penerimaan kita terhadap orang lain, maka semakin mudah pula kita melestarikan dan mempererat hubungan kita dengan orang lain. Didukung juga dengan sikap positif yang dapat dijalankan dengan membuat komunikasi dalam keluarga penuh kejujuran, setiap pernyataan yang di utarakan realistis, masuk akal dan tidak dibuat-buat, selain itu setiap anggota keluarga benar-benar mengenal perilaku masingmasing, serta semua elemen keluarga harus dapat belajar cara tidak menyetujui tanpa adanya perdebatan.

\section{Simpulan}

Adanya hubungan antara penggunaan gadget terhadap pola komunikasi dengan keluarga pada siswa-siswi kelas $\mathrm{x}$, tingginya angka penggunaan gadget menyebabkan minimnya komunikasi yang efektif antara remaja dengan keluarga dan interaksi pada remaja yang serba membutuhkan gadget sebagai medianya.

\section{Referensi}

Dhamayanti, M. (2009). Overview adolescent health problems and services. IDAI. http://www.idai.or.id / remaja / artikel.

Djamarah dan Syaiful, B.(2004). Pola Komunikasi Orang Tua dan Anak Dalam Keluarga, Jakarta: Rineka Cipta. 
Faletehan Health Journal, 6 (2) (2019) 50-55

www. journal.Ippm-stikesfa.ac.id/ojs/index.php/FHJ

ISSN 2088-673X | 2597-8667

Manumpil, B., Ismanto, Y., Onibala, F. (2015). Hubungan Penggunaan Gadget Dengan Tingkat Prestasi Siswa Di Sma Negeri 9 Manad. Ejoural Keperawata Volume 3(2). FK Unsrat Manando.

Karpinski, AC. (2009). A description of facebook use and academic performance among undergraduate and graduate students. Paper presented at the Annual Meeting of the American Educational Research Association. San Diego. CA.

Kementerian Komunikasi dan Informatika (Kominfo). (2014). Pengguna internet di Indonesia capai 82 juta. (Di unduh dari http://kominfo.go.id tanggal 29 Maret 2018).

Kementerian Komunikasi dan Informatika (Kominfo). (2014). Siaran Pers TentangRiset Kominfo dan UNICEF. (Diunduh dari http://kominfo.go.id tanggal 21 Desember 2018)

Liptan6.com. (2016). Anak Asuhan Gadget. (Diunduh dari https://www.liputan6.com tanggal 21 Desember 2018)
Notoatmodjo, S. (2012). Metodologi Penelitian Kesehatan. Jakarta: Rineka Cipta.

Nursalam. (2009). Konsep Dan Penerapan Metodologi Penelitian Ilmu Keperawatan Ed. 2. Jakarta: Salemba Medika

Okezone.com. (2018). Indonesia Pengguna Smartphone Ke-4 Dunia, Begini Tekad Menperin Dongkrak Industri Telematika. (Diunduh dari https://economy.okezone.com tanggal 21 Desember 2018),

Septiyani dan Intan. (2016). Anak Fasih Media Sosial Orang Tua Jangan Gaptek. Jakarta: EGC

Steiner, Adair, and Barker, Th. (2013). The Big Disconnect. Harper Collins Publishers: New York (USA)

Yusuf, SLN. (2015). Psikologi Perkembangan Anak dan Remaja. Bandung: Remaja Rosdakarya Offset. 